\title{
Gemination at the Horizons: East and West in the Mythical Geography of Archaic Greek Epic
}

\section{DIMITRI NAKASSIS \\ University of Texas at Austin}

SUMmary: This paper examines descriptions of remote places in archaic Greek epic. I argue that Homeric cosmic geography consists of two complementary models, one in which the sun rises and sets at a single locus - the axis mundi-as in the Theogony, and another in which sunrise and sunset take place on the eastern and western horizons respectively. Conflation of these models in the Odyssey results in the gemination of peoples and places associated in myth with the sun. This not only explains some recurrent patterns in Homeric geography and their thematic importance to Odysseus' travels, but also resolves some traditional interpretive difficulties with descriptions of the edges of the earth in archaic epic.

FROM ANTIQUITY ONWARDS, HOMERIC GEOGRAPHY has been a topic of intense scholarly scrutiny and debate. Recent scholarship has tended to the "idealist" view that the wanderings of Odysseus are best understood as taking place in the mythical geography of the eschata gaies (the "edges of the earth") and not a real geography of the Mediterranean. ${ }^{1}$ Yet paradoxically there has been little

* I would like to thank Jonathan Burgess, Sarah James, Chris Lovell, Jim Marks, and Tim Stover for their helpful comments, as well as Cynthia Damon and an anonymous TAPA reader for greatly improving the text. Most of all I want to thank Erwin Cook for his constant guidance and encouragement. An earlier version of this paper was presented at the 2002 meeting of the APA in Philadelphia.

${ }^{1}$ This point is forcefully made by Heubeck 1989: 4-5. Recently Hartog 2001: 23-26, 28 has discussed real and imaginary Homeric geographies. Ballabriga 1998 argues that we need to supersede the distinction between real and imaginary geography, yet he essentially reproduces ancient interpretations of Homeric geography using later Greek texts and modern maps. Ballabriga assigns a real location to every entity in the Odyssey, implying that Homeric descriptions are always reflections (albeit fabulous ones) of real peoples and places. Thus according to Ballabriga 1998: 180-84 the description of Ogygie, Kalypso's island, reflects 6th century в.c. knowledge of the Atlantic Ocean, so Kalypso is a recent poetic invention of the Homeridai designed to lengthen Odysseus' absence from Ithake. 
attempt to explain Homeric descriptions of the eschata as a coherent system of thought that corresponds to an identifiable mythical logic. ${ }^{2}$ Instead, individual passages are examined in isolation, or connections between passages are explained by recourse to general phenomena. For example, Nagy and Ballabriga have both noted that pairs of identical (or similar) entities are often located on the eastern and western horizons in archaic epic. ${ }^{3}$ Most prominent are the Homeric Aithiopes, who are said to live split in two: some reside at the sunrise, others at the sunset (see section 2 below). Both Nagy and Ballabriga identify this configuration as a specific instance of a general phenomenon that they term coincidentia oppositorum, originally a phrase used by Mircea Eliade in his comparative studies of religion to describe entities that manifest opposing attributes. ${ }^{4}$ Thus the Homeric instances of doubling at the horizons are seen as particular cases of a cross-cultural phenomenon, and moreover are explained by the idea of convergence at the horizons. ${ }^{5}$ Although my findings are not incompatible with this view, I hope to show that the gemination of people and places at the eschata, which is more extensive than has been previously noted, finds a clear motivation in the alternative ways in which archaic Greeks could imagine and describe the solar phenomena of sunrise and sunset.

In the Hesiodic description of Tartaros, the alternation between night and day at sunrise and sunset is represented as occurring at a single locus; that is, the sun rises and sets at the same place. This "uni-polar" model of solar change coexists in archaic epic with a "bi-polar" model in which the sun rises on the eastern horizon and sets on the western horizon. The result of their conflation is an impulse to balance mythical peoples and places at the horizons. The Aithiopes, for example, who are closely associated with the sun in myth, are located near the places at which the sun rises and sets. Moreover, because the spatial polarity between east and west is linked to a series of other oppositions such as light: dark and life : death, the spatial configuration of mythical geography also informs the thematics of travel at the edges of the earth in archaic epic.

${ }^{2}$ Recent exceptions include Burgess and Cook 1995.

${ }^{3}$ Ballabriga 1986: 75-146; Nagy 1990: 237, 1999: 206.

${ }^{4}$ Eliade 419-29. Nagy 1999: 185 observes another coincidentia oppositorum in the

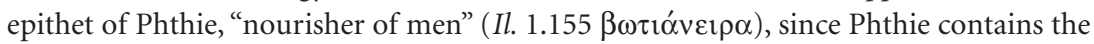

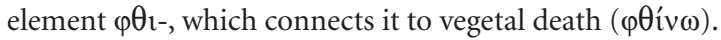

${ }^{5}$ Ballabriga 1998: 51 has recently admitted that his previous work (1986) treated coincidentia oppositorum too much as an abstract and primitive archetype. 


\section{THE UNI-POLAR MODEL}

In the Theogony, Tartaros is described as a place that simultaneously contains

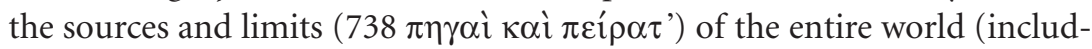
ing itself). The passage is often regarded as obscure and sometimes for this very reason suspected of being an interpolation. ${ }^{6}$ Bergren, however, has shown through a detailed study of Greek $\pi \varepsilon^{\prime}$ p $\alpha \rho$ that the Hesiodic description of Tartaros expresses two different and complementary ways of conceptualizing the border of a body in archaic Greek thought: "conceived from the outside in, the border is the source, the place where the body begins, from the inside out, it is the line of the furthest outward extension of the body, the point beyond which that body is no more and another begins." ' So, viewed from a Greek ("inside out") standpoint, Tartaros is located at the edges of the earth (Th.

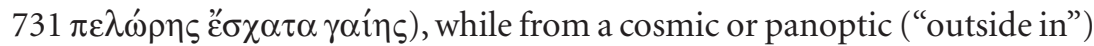
perspective, Tartaros is cosmologically central, a nexus that mediates between the cosmic forces of the world. Center and periphery are thereby conflated.

Bergren's distinction between "inside out" and "outside in" conceptions of borders is also useful for understanding the account of solar change in the Theogony (746-51):

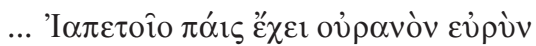

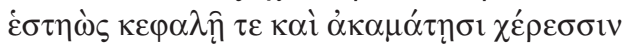

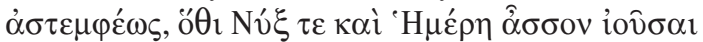

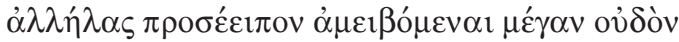

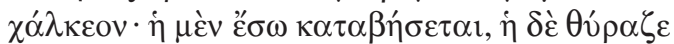

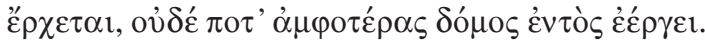

... the son of Iapetos stands holding wide heaven with his head and unwearying hands unyieldingly where Night and Day, coming towards each other, address one another, crossing a large bronze threshold; one descends within, and the other comes forth, and the house never encloses both of them. ${ }^{8}$

In Hesiod, Tartaros is clearly the place where the sun both rises and sets; that is, solar change is conceptualized as occurring at a single threshold. One

${ }^{6}$ West 1966: 50, 356-59 argues for interpolation, while Johnson defends the integrity of the passage.

${ }^{7}$ Bergren 115. Bergren 41 defines $\pi \varepsilon i ́ \rho \alpha \rho$ as "that which forms the limit of the outward extension of anything." Parvan, the Vedic Sanskrit cognate, is defined as "that at which one thing ends and another begins" (Bergren 94).

${ }^{8}$ Translations from Greek are my own. 
interpretation is that this threshold corresponds to the entire edge of the earth, in which case Night and Day would hail each other from opposite horizons at sunrise and sunset. ${ }^{9}$ However, this is unsatisfactory, not only because o $\theta \mathrm{r}$ suggests a more restricted area than the earth's surface, ${ }^{10}$ but also because the basic thrust of the analogy is that Night and Day address one another as they enter and exit their house; to make the house's threshold as abstract as the entire surface of the earth significantly weakens the force of the analogy. Instead, I suggest that the solar threshold is conceived of as a fixed point close to (if not at) the entrance to the Underworld. ${ }^{11}$

As Fränkel notes, Hesiod's description "ist nicht als Topographie gemeint," otherwise the solar threshold would have to be in east and west simultaneously. ${ }^{12}$ Rather than focusing on explaining the Hesiodic description of Tartaros as rational geography, we need to understand the role of Tartaros according to archaic Greek conceptions of the cosmos. As the locus of the roots of the earth and sea (Th. 728) and the sources and limits of the earth, sea, heaven, and itself (Th. 736-38), Tartaros functions as the axis mundi in the cosmic/panoptic "outside in" perspective, for it is here that Atlas supports the heavens. That Atlas supports heaven, and thereby serves as a boundary between heaven and earth (cf. Od. 1.53-54), fits into the model of Tartaros as a cosmic nexus that contains the sources and limits of the natural world. The location of a solar threshold in Tartaros also corresponds to this pattern, so that Tartaros is the source and limit of the solar cycle. ${ }^{13}$ The association of

${ }^{9}$ Johnson 21-22, Pellikaan-Engel 11-33. That is, at sunrise, Day at the eastern horizon would hail Night at the western horizon; their positions would be reversed at sunset. According to this explanation, both Night and Day would be at the threshold of the house of Night, which is the edge of the earth. Those who interpret the threshold as corresponding to the earth's surface use the textual variant of line 748, which reads $\alpha \mu \varphi i \varsigma$ غ̇ov̂ $\sigma \alpha 1$ (Pellikaan-Engel 31-38, Johnson 22). I read $\hat{\alpha} \sigma \sigma o v$ iov̂ $\sigma \alpha$ l with West 1966, whose text I use. While the proem of Parmenides (1.11-14) supports the former reading, the parallel passage in the Odyssey (10.82-86, see section 4 below), according to which "the paths of night and day are close together," supports the latter (West 1966: 366-67).

${ }^{10}$ West 1966: 367.

${ }^{11}$ My interpretation of the solar threshold in Hesiod is corroborated by a black-figure lekythos by the Sappho painter that shows Night and Eos moving in opposite directions next to an entrance to Hades (Metropolitan Museum 41.162.29, ABV[=Beazley] 507.6, $702, A_{d d e n d a^{2}}$ [=Carpenter] 126). Interpretive issues raised by the vase are well discussed by Pinney and Ridgway and more recently by Burgess 196-97.

${ }^{12}$ Fränkel 115 n. 21; cf. Kahn 82.

${ }^{13}$ Cf. Nagy's 1999: 196 discussion of Okeanos as a cosmic and solar border and a generative source. 
the threshold of the solar cycle with that of the life cycle (i.e., light and dark correspond to life and death ${ }^{14}$ ) also accounts for the spatial association of Tartaros with death and the land of the dead (Th. 759, 767-74). ${ }^{15}$ Tartaros thus acts as a threshold along three different axes: the horizontal (the plane of the earth), the vertical (heaven, earth, and the underworld), and the temporal (the solar and life cycles). ${ }^{16}$

This collocation of center and periphery is also found in Homer: Kalypso's island, Ogygie, is described as ó $\mu \varphi \alpha \lambda$ ó $\varsigma \alpha \alpha \lambda \alpha \sigma_{\sigma \sigma \eta}$, the "navel of the sea" (Od. 1.50 ), yet is remote from the human and divine world, as Hermes remarks to Kalypso (Od. 5.100-102). From this perspective it is significant that Kalypso is the daughter of Atlas, who is adjacent to the house of Night in Tartaros and constitutes the vertical axis that unites the cosmos. ${ }^{17}$ Kalypso's genealogical relationship with Atlas may also explain why a fir tree on Ogygie is described as being as tall as heaven (Od.5.239 ov $\rho \alpha v o \mu \eta \dot{\kappa} \kappa \varsigma) .{ }^{18}$ Ogygie therefore shares much with Hesiodic Tartaros, including the conflation of center and periphery.

\section{THE BI-POLAR MODEL}

As we have seen, there is in Homer, as in Hesiod, a geography in which the edges of the world are simultaneously conceived of as central. But Homeric poetry also contains elements of a naturalized geography. The archaic conceptualization of boundaries, as described by Bergren, shows how Homeric geography may combine these two perspectives into a unified concept, although they may seem separate and contradictory to us. ${ }^{19}$ It is not so much that the Hesiodic model lacks awareness of a bi-polar cosmology, but rather that the perspective of the Theogony is markedly panoptic or "Olympian" in perspective, while Homeric descriptions of the edges of the earth are often, though by no means exclusively, focalized through the perspective of human action. As Clay has noted, Iliadic descriptions of the cosmos that represent Olympian perspectives of the world are in fact similar to the cosmology of

${ }^{14}$ Frame, and see below.

${ }^{15}$ West 1966: 370-71 brackets Th. 768 and 774, which mention Hades and Persephone by name, but the passage leaves no doubt that Hesiod is discussing the land of the dead, ruled by a chthonic god and guarded by a dog (Kerberos' name is omitted).

${ }^{16}$ Johnson 12-13 notes Tartaros' mediation of linear and cyclical phenomena, remarking that "it is as much about time as it is about space."

${ }^{17}$ Cf. Frame 166-69.

${ }^{18}$ Eustathios (1390.7 Stallbaum) explicitly identifies Ogygie as an axis mundi; see Buffière 579-80 and Nagler 145-46 n. 13.

${ }^{19}$ For the sake of clarity in the discussion below I present Homeric geography as consisting of two complementary and coexisting systems. 
the Theogony. ${ }^{20}$ Thus, which of the two models is employed in any given description of remote places largely depends on the context of the passage and how it is focalized. ${ }^{21}$

The clearest example of gemination at the horizons in the Odyssey is a description of the Aithiopes that has long puzzled commentators. ${ }^{22}$ The Aithiopes are described as a people split in two; some of them live near the sun's rising, others near its setting $\left(O d .1 .22-24^{23}\right)$ :

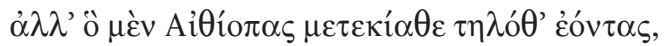

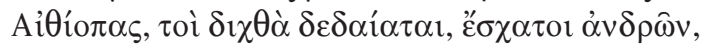

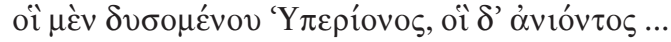

But he [sc. Poseidon] passed over to the Aithiopes living far away, the Aithiopes who live split in two, farthest of men, some by Hyperion's setting and others by his rising ...

Populations of eastern and western Aithiopes living at the edges of the earth appear elsewhere in early Greek literature, typically in association with the sun: Helios rests his horses among the Aithiopes in the west (A. fr. 192 Radt), ${ }^{24}$ and rises in the east, again among the Aithiopes (Mimn. fr. 12 West). Like other है $\sigma \chi \alpha \tau$, they are thought of as living on the shores of Okeanos (Il. 23.2056) and enjoying the open presence of the gods. ${ }^{25}$ Yet the Aithiopes were identified with historical African peoples by the time of Herodotos, who sought

${ }^{20}$ Clay 137. The relevant passages, discussed by Clay, are Il. 5.767-77, 8.1-27, 14.153$62,15.1-366,18.480-608$.

${ }^{21}$ Thus, the presence/absence of evidence for each model is largely a function of the subject matter and length of Hesiodic and Homeric poetry. I also note that while humans are entirely absent from Hesiodic descriptions of the eschata, most of these passages in the Odyssey are narrated by Odysseus.

${ }^{22}$ E.g., S. West 75 comments, “The geographical detail is distracting, as we naturally wonder which group Poseidon is visiting," but Poseidon's location seems to be settled at Od. 5.283, when on his return he crosses the Solymoi mountains, presumably in Lykia (Il. 6.184, 204, Hdt. 1.173). Of course, one would not necessarily be wondering about this if one viewed the cosmos in the way I propose.

${ }^{23}$ The text of the Odyssey is van Thiel's.

${ }^{24}$ The western location of the Aithiopes in the Aischylos fragment can be inferred by the fact that Helios is resting his horses, which is most appropriate at the end of the day.

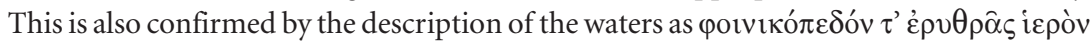
$\chi \varepsilon \hat{v} \mu \alpha \theta \alpha \lambda \alpha \sigma_{\sigma \sigma}$ (A. fr. 192.1-2 Radt), as red is the color of the west. The island of the western cattle of the sun is called Erytheia (see section 5 below).

${ }^{25}$ The Phaiakes also enjoy direct contact with the gods (Od. 7.199-203) and consider themselves है $\sigma \chi \alpha \tau$ (Od. 6.205, 7.321-22). 
to reconcile this historical localization with Homer by positing the existence of other tribes of Aithiopes to the east and west. ${ }^{26}$ This accords with Herodotos' general geographical model, based on cosmic balance: the existence of Hyperboreans implies the matching Hypernotians, and the southern Nile is paralleled exactly by the northern Ister. ${ }^{27}$ Nevertheless, Homeric poetry clearly describes the Aithiopes as living at the edges of the world on the banks of Okeanos, and not in an historical Africa. ${ }^{28}$ Indeed, they are marked by their proximity to the rising and setting sun; this is the literal meaning of the Od$y$ ssey passage, and is implied by the fact that their king Memnon is the son of the Dawn, Eos. ${ }^{29}$ Thus, viewed from the uni-polar model of solar change, the Aithiopes are thought of as simply living near the home of the sun, but in the naturalized bi-polar model they are located at both horizons.

\section{KALYPSO AND KIRKE}

Using the framework created by this analysis, we may revisit the Homeric localization of Kalypso. From her sailing instructions to Odysseus, Kalypso can be localized in the far west: when departing from Ogygie, Odysseus sails for 18 days and nights in an easterly direction, and at last arrives at Skherie. Skherie is situated on the remote western fringes of the Greek world, hence Ogygie must be located even further to the west. ${ }^{30}$ Kalypso's geographical location corresponds to her genealogy as the daughter of Atlas ( $\mathrm{Od} .1 .52)$, since Atlas supports the earth from Tartaros (Hes. Th. 517-19, 746-48), itself often associated with the far west (A. Pr. 348-50). Frame has noted the close corre-

${ }^{26}$ Hdt. 4.183 (western Aithiopes), 7.70 (eastern Aithiopes). The long-lived Aithiopes against whom Kambyses campaigns are described as living at the ends ( $\varepsilon \sigma \chi \alpha \tau \alpha)$ of the earth (Hdt. 3.25).

${ }^{27}$ Hdt. 4.36, 2.33-34, discussed by Romm 1989 and Hartog 1988: 14-19. Cf. Hedreen 324-30 on the localization of the cult of Achilles in the Black Sea.

${ }^{28}$ The Aithiopes are not convincingly associated with the historical group in Africa before Hekataios (Jacoby 1F326-27). The two passages that are often cited in support of archaic Greek placement of the Aithiopes in Africa are Od. 4.84 and Hes. fr. 150 Merkelbach-West. Neither passage makes topographical sense, read historically. Menelaos' itinerary (Od.4.83-89) reads more like Odysseus' travels than it does an historical sevenyear sail around the Mediterranean (cf. S. West 198), and Hesiod fr. 150 is organized genealogically, not geographically (West 1985: 85): the Aithiopes appear in the same line with Libya as well as with the Skythians (Hes. fr. 150.15 Merkelbach-West).

${ }^{29}$ Od. 4.188, Pi. O.2.83, Hes. Th. 984-85.

${ }^{30}$ For the eastern direction of Odysseus' journey see the comments of Germain 534 and Hainsworth 276-77. Skherie's location west of Greece is made clear by Alkinoos' statement that the Phaiakes have traveled even as far as Euboia (Od. 7.321-24). See Anderson 6, Burkert 1992: 159 n. 10, Cook 1992, and West 1988: 172. 
spondence between the Homeric description of Kalypso and the Hesiodic description of Styx, where "Ogygian" is used of the Stygian water (Th. 8056) as an adjective meaning "primeval." 31 Moreover, as one who "covers" (or "conceals") and lives in a cave, she is associated with the setting sun, darkness, and death. ${ }^{32}$

Kirke's island of Aiaie, on the other hand, is firmly located by the Odyssey in the east, near Dawn and Helios (12.1-4):

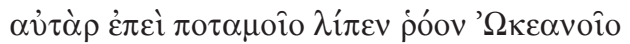

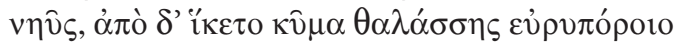

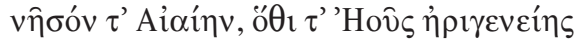

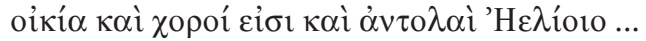

But when our ship left the stream of river Okeanos, and came back to the wave of the wide-crossed sea and to the island Aiaie, where the house of early-born Dawn and her dancing floors are, and the risings of Helios ...

There is a strong emphasis on the location of Aiaie relative to the (rising) sun. The island's name seems to be an adjectival formation from Aia, where according to Mimnermos (fr. 11a West) a golden chamber held the rays of Helios. ${ }^{33}$ Kirke's genealogy is significant, for she is the daughter of Helios and Perse (or Perseis), daughter of Okeanos (Od. 10.138-39, Hes. Th. 956-57). Her brother Aietes lives at Aia, perhaps a day's sail away. ${ }^{34}$ Moreover, strange solar phenomena occur at Kirke's island, for Odysseus and his men are unable to locate the sunrise or sunset (Od.10.190-92). The lack of spatial orientation suggests that Aiaie is near the house of the sun, where it is impossible to ascertain east and west from the sun's movements. ${ }^{35}$ Kirke's

${ }^{31}$ Frame 166-69 and Ballabriga 1986: 92-95. Even in the unlikely case that the adjective's use is based on Homer's portrayal of Kalypso, it amounts to an ancient commentary on her nature.

${ }^{32}$ Frame 21, 73-74; Crane 15-29.

${ }^{33}$ A chamber of rays is naturally located in the east so that the sun can "recharge" before rising in the morning. On the invention of Aiaie from Aia see Strabo 1.2.10, 1.2.40.

${ }^{34}$ The Planktai, through which Jason passed on his return from Aia, are located near Skylla and Kharybdis, which Odysseus and his crew encounter on the same day they depart from Aiaie (Od.12.59-72). I consider the equation of Aia with historic Kolkhis a later development (see Allen 89-90).

${ }^{35}$ Contra Ballabriga 1998: 141, who argues that Odysseus' inability to orient himself indicates that Aia is located in the "Great North" along with the Laistrygones, following the untenable explanation of Krates (see below n. 45). 
geographical location is therefore at the eastern horizon, associated with the sun and light, thereby complementing, and contrasting with, Kalypso's. ${ }^{36}$

The similarities between Kirke and Kalypso are so striking that Analytic scholars have long considered one, usually Kalypso, to be "derived" from the other. ${ }^{37}$ This is true to the extent that the existence of one solar figure seems to have drawn the other into a reciprocal relationship. ${ }^{38}$ Both are divine women who attempt to restrain Odysseus but eventually act as helpers. ${ }^{39}$ Both live on islands with pronounced affinities to the "Isles of the Blessed," and they are also linked by a number of textual correspondences in the Odyssey ${ }^{40}$ Indeed, the similarities between Kirke and Kalypso are so strong that the two figures were even conflated in antiquity. ${ }^{41}$ I therefore suggest that Kirke and Kalypso represent a geminated pattern similar to that of the Aithiopes. ${ }^{42}$ Instead of an entire people split in two, here we have mythological doublets located at opposite ends of the earth and displaying closely similar characteristics and narrative functions. Kalypso is, moreover, associated with the axis mundi through her father, Atlas, and her island is at once central and peripheral, like Hesiodic Tartaros. Kirke, on the other hand, is a daughter of Helios who lives near the house of the sun. ${ }^{43}$ Thus, as individuals, they are consistent with the Hesiodic uni-polar model, but as a pair, they reflect a bi-polar, naturalized geography. If my model explaining the gemination of the Aithiopes in the distant east and west is correct, then the presence of similar characters located on both horizons can be seen as part of the same general pattern.

${ }^{36}$ A number of scholars place Kirke and Aiaie in the west (see below n. 70). However, prior to arriving at Aiaie Odysseus encounters the Laistrygones, who I argue are localized in the extreme east (see section 4 below). The fact that the sons of Kirke and Odysseus are said in the Theogony (Th. 1011-16) to rule over the Tursenoi, probably the Etruscans (West 1966: 435-36), cannot outweigh the clear Homeric evidence that Aiaie is at the eastern horizon.

${ }^{37}$ For a thorough discussion of Kalypso and her relation to Kirke see Crane 31-60.

${ }^{38}$ That is to say, the similarities between the two are not merely the result of the fact that they both play the role of the "female helper" type (Crane 61-86, Nagler) but were further articulated over time due to the impulse to balance figures at the eastern and western horizons.

${ }^{39}$ Cook 1992: 249-50, Nagler.

${ }^{40} \mathrm{Od}$. 5.230-32 = 10.543-45, and 5.178-79 = 10.343-44; see also Od.9.29-32. For Ogygie and Aiaie as islands with marked similarities to the Isles of the Blessed see Crane 15-29.

${ }^{41}$ Kalypso's island is sometimes called Aiaie (Propertius 3.12.31, Mela 2.120), and Telegonos is sometimes the son of Kalypso (Eust. 1796.35 Stallbaum) but elsewhere of Kirke (Hes. Th. 1011-18).

${ }^{42}$ Ballabriga 1986: 91 notes that Aiaie is the eastern counterpart of western Ogygie.

${ }^{43}$ Nagler 149 notes the typical association of the "dread goddess" with the axis mundi through a male relative, typically her father: Atlas in Kalypso's case, Helios in Kirke's case. 


\section{LAISTRYGONES AND KIMMERIOI}

The Laistrygones and Kimmerioi are another Odyssean pair of mirror groups whose features are determined by their relationship to the sun. The Laistrygonian city, Telepylos, is located in a place where the paths of night and day lie close together $(\mathrm{Od}$. 10.82-86):

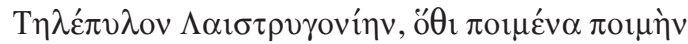

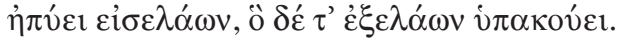

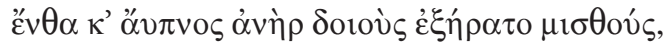

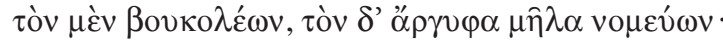

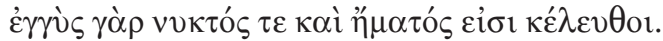

Laistrygonian Telepylos, where shepherd hails shepherd driving in his flocks, and the other driving them out answers him. There an unsleeping man could earn double wages, one herding cattle, the other pasturing silvery sheep. For the paths of night and day are close together.

The parallels between this passage and the Hesiodic description of Tartaros are clear: in both, solar change occurs at a single place, and the alternation of day and night is described by the movements of individuals simultaneously "coming in" and "going out" in close proximity to one another, reinforced in the case of Telepylos by the motif of the sleepless herder. It seems apparent from this description in the Odyssey that the Laistrygones enjoy perpetual sunlight.

The Kimmerioi, in direct contrast, live in a land of perpetual darkness, at an entrance to the Underworld (Od.11.14-19): ${ }^{44}$

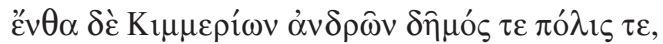

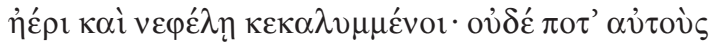

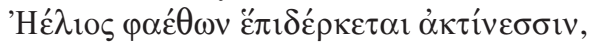

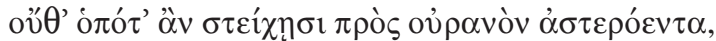

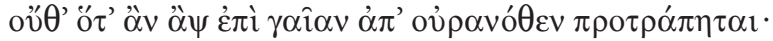

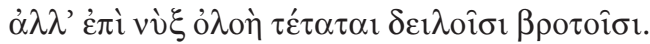

There is the demos and polis of the Kimmerian men, hidden in fog and cloud; nor does shining Helios ever look upon them with his rays,

${ }^{44}$ This passage describing the eternal night of the Kimmerioi echoes Hes. Th. 757-61, where Tartaros is described. Clearly, I do not view the Homeric Kimmerioi as the historical tribe who entered Asia Minor in the 8th and 7th centuries B.c.; see the discussion in Heubeck 1989: 77-79, with which I concur. 
neither when he climbs towards starry heaven, nor when he turns back to the earth from heaven.

But a destructive night spreads on the wretched mortals.

Darkness is strongly associated with the west, as is the gate to the land of the dead. On the other hand, the perpetual daylight of the Laistrygones connects them with the east, for the east is the home of dawn and the light. ${ }^{45}$ Indeed, Telepylos is quite close to Kirke's Aiaie, requiring only a short sail by Odysseus and his men ( $O d$. 10.133-35). Aiaie and Telepylos are further linked by the motif of solar confusion: the proximity of day and night at the end of the world obscures clear distinctions between the two. The Laistrygones, moreover, live in a place that means "far away gate," which can be understood as referring to the place through which the sun passes each morning at dawn. ${ }^{46}$ The corresponding western gate is referred to in the Odyssey as the "gates of the Sun"

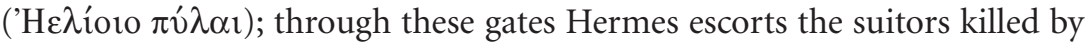
Odysseus into the Underworld. ${ }^{47}$ The Kimmerioi, who live by the entrance to the Underworld, correspond closely to Kalypso's mythological and thematic associations to Tartaros. As was the case with Kalypso and Kirke, the Laistrygones and Kimmerioi are similar as types: they are both peoples with political institutions $\left(\delta \hat{\eta} \mu \varsigma_{\varsigma}\right.$ and $\left.\pi \alpha^{\prime} \lambda \iota\right)$ that are relatively rare in the mythical lands of the Apologoi ${ }^{48}$ Thus, we may view the pairing of the Laistrygones and the Kimmerioi as parallel to that of Kirke and Kalypso.

${ }^{45}$ Some scholars, following Krates (in $\Sigma O d$. 10.86 Dindorf), have located the Laistrygones in the far north (Frame 63, Ballabriga 1998: 123-24), but as Heubeck (1989: 48 with bibliography) and others have pointed out, this position is erroneous. Explaining the Homeric description of the Laistrygones according to the thematic association of the east with light, among other things, obviates the need for Homer to be drawing on information about Northern Europe and/or Norwegian fjords!

${ }^{46}$ Frame 60 translates Telepylos as "Far-Gate," although clearly I disagree with his placement of Telepylos in the far north. West 1997: 406-7 likewise translates it as "Distant Portal" and compares it to the gate of the sun at Mashu in the Epic of Gilgamesh.

${ }^{47}$ Od. 24.11-14, and see the discussion in Heubeck 1992: 360-61.

${ }^{48}$ See $\mathrm{Od}$. 11.14 for the Kimmerioi, $\mathrm{Od}$. 10.104-18 for Laistrygones, who also have an astu and an agora. Only the Phaiakes, who inhabit a border realm between the Greek world and the Otherworld (Cook 1992), are also political, although the floating island of Aiolos is called a polis ( $\mathrm{Od}$. 10.13). In viewing the Apologoi as dominated by the primitive, I follow the mainstream of the secondary literature on the nature of the edges of the earth in the Odyssey (e.g., Hartog 2001: 21-26); cf. Cook 1995: 49-92, esp. 70-74, on "hierarchies of culture" in the Apologoi. 


\section{THE CATTLE OF THE SUN AND THE CATTLE OF GERYON}

The "Cattle of the Sun" offer a more complex example of doubling at the horizons in Greek mythology. In the Odyssey, Helios demands the punishment of Odysseus' men for sacrificing his immortal cattle, in which he takes pleasure as he rises and sets (12.379-81):

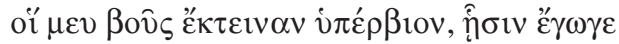

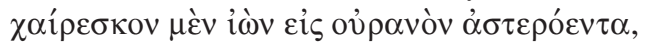

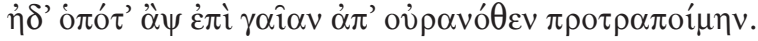

They [sc. the companions of Odysseus] killed my cattle insolently, in which I took pleasure both ascending into the starry sky and when I turned back again from the sky to earth.

Here, the compatibility of the two coexisting systems is clear: this description may be conceptualized in the uni-polar model of solar change, in which case a single herd of cattle is located at both sunrise and sunset, or it may refer to two herds on opposite horizons in the bi-polar model of solar change. ${ }^{49}$ But the narrative places the cattle killed by Odysseus' men on Thrinakie, which is located in the east, and is reached on the same day that Odysseus departs from Aiaie. Cook has argued that Helios' eastern herd on Thrinakie is balanced outside of the Odyssey by the western cattle of Geryon. ${ }^{50}$ Geryon's cattle are located on the island Erytheia, whose "ruddy" name is reminiscent of the sunset, and which is located near the Hesperides past the stream of Okeanos (Hes. Th. 288-94, Hdt. 4.8.2). Indeed, the nymph Erytheia is explicitly linked to Helios in a fragment of Antimachos (fr. 66 West) in which she sends Helios to the east in a golden cup. ${ }^{51}$ Here again, as with peoples within the Odyssey, a strong association with the sun yields a gemination of solar cattle into paired

${ }^{49}$ Helios' description of his path across the sky helps elucidate another topographical crux at Od. 15.403-4, where Eumaios describes the island Syrie as "above Ortygie, where [are] the $\tau \rho o \pi \alpha i$ (turnings) of Helios." While Ortygie has been taken as Delos or the Syracusan island, the use of $\pi \rho \tau_{\rho} \alpha \pi$ oí $\mu \eta v$ in our passage $(O d .12 .379-81)$ indicates that the "turnings" of Helios occur at the horizon(s), where his cattle are kept. This would also explain why Ortygie is mentioned in connection with Eos (Od.5.123), and why the people of Eumaios' homeland do not experience hunger or sickness (Od. 15.407-11). For a discussion of this crux see Hoekstra 257, Ballabriga 1986: 16-22 and 1998: 99-108, with bibliography.

${ }^{50}$ Cook 1995: 85-86.

${ }^{51}$ Erytheia is the daughter of Geryon in Paus. 10.17.5 and Stephanus of Byzantium. 
groups located at sunrise and sunset, the latter of which now belong to a multiform of Hades..$^{52}$ In the uni-polar model of solar change, however, the cattle of the sun are herded around his house/gate at the cosmic axis mundi (i.e., Hesiodic Tartaros). ${ }^{53}$

\section{THE ENDS OF THE EARTH IN RELATED TRADITIONS}

The perspectives offered here on the archaic conceptualization of the edges of the world allow us to explain particularities of their description and the spatial patterning of those who live there (the " $\check{\sigma} \sigma \alpha \tau \sigma \mathrm{o})$. In the tradition preserved in Hesiod, there is a single gate of Night and Day located at the edge of the earth, at the entrance to the Underworld where Atlas supports the sky. This gate is also traditionally associated with Herakles' katabasis, in particular the traditions in which he battles Hades at Pylos, "the gate," ${ }^{54}$ and his voyage to the Hesperides in the far west. ${ }^{55}$ The pillars of Herakles, often identified with the rocks at Gibraltar, ${ }^{56}$ are located at the western edge of the world, like Atlas, who is sometimes described as holding the column that supports the sky $(\mathrm{Od}$. 1.53-54) or even as the column itself (Hdt. 4.184.3), so that the pillars of Herakles may plausibly be considered a multiform of the axis mundi. They were probably also influenced by the pillars of Gadeira/Cadiz in the Phoenician cult of Melqart, who is treated by Herodotos as an equivalent to Herakles. ${ }^{57}$

The collocation of solar and life cycles, too, has strong parallels, this time in Egyptian and Near Eastern traditions. The uni-polar model of solar change

${ }^{52}$ Crane 128, Croon, and Davies (with extensive bibliography). An analogy can be drawn here to the herds at Telepylos. If we imagine that the Laistrygonian herders are returning their cattle to the Hesiodic house of Night and Day, then the cyclical pasturing of their herds parallels the solar cycle. Following Frame 63, I argue that this association of herds with solar change indicates a common source of inspiration, namely the idea of solar cattle kept by Helios at his house at the edges of the world.

${ }^{53}$ Note that in the Hymn to Apollo (411-13) Helios' cattle are located at Cape Tainaron, which is elsewhere an entrance to the Underworld (Paus. 3.25.5, Plut. Mor. 560E). While Tainaron is clearly not located at the edges of the earth, but on the Greek mainland, there is still a collocation of the cattle of Helios with the gate of the Underworld.

${ }^{54}$ Il. 5.395-97, echoed by Pi. O. 9.28-35. See Croon 57, Davies 289 n. 70, and Nagy 1990: 225-26. It is unclear which Pylos is meant by the Iliad; most scholia place this battle at Messenian Pylos, although Pausanias 6.25.2 argues for Eleian Pylos, where Hades had a temple; see Kirk 101-2.

${ }^{55}$ Davies.

${ }^{56}$ The pillars of Herakles are first mentioned by Pindar (O. 3.44, N. 3.21, I. 3/4.30, fr. 256 ) as a barrier that cannot or should not be crossed. See also Romm 1992: 17-19.

${ }^{57}$ Hdt. 2.44; see the comments of Burkert 1985: 210 and West 1997: 464-65. 
is described in the Epic of Gilgamesh (henceforth $E G$ ), in which a mountain with twin peaks, Mashu, watches over sunrise and sunset (EG IX 38-45):58

To Mashu's twin mountains he came, which daily guard the rising [sun,] whose tops [support] the fabric of heaven, whose base reaches down to the Netherworld. There were scorpion-men guarding its gate, whose terror was dread, whose glance was death, whose radiance was fearful, overwhelming the mountainsat sunrise and sunset they guarded the sun.

Mashu serves, moreover, as the boundary between the living and dead, controlling access to the Otherworldly garden of the gods ${ }^{59}$ But Mesopotamian cosmology also locates mountains and gates of sunrise and sunset at the horizons in a naturalized model of solar change; the gate of sunset is also an entrance to the Underworld, ${ }^{60}$ while the gate of sunrise provides the dead with a way out to light and life. ${ }^{61}$ Egyptians, too, conceived of solar mountains located at the eastern and western edges of the earth, which were likewise guarded by animal divinities. ${ }^{62}$ In Egyptian cosmology, twin sycamores of turquoise mark the eastern door from which Re issues, the gate through which Atum, the setting sun, passes daily, and a door to the Underworld. ${ }^{63}$ A hymn

${ }^{58}$ For the Epic of Gilgamesh I have used the translation of George with consultation of Pritchard. Words in brackets indicate breaks in the tablet that can be restored with certainty. Note that Mashu means "twins" in Akkadian (Speiser at Pritchard 88 n. 147). West (1997: 142) compares Mashu with the Greek gates of the Sun.

${ }^{59}$ EG IX 171-96. For a discussion of paired mountains of sunrise and sunset in Babylonian texts see Heimpel 143-46.

${ }^{60}$ Horowitz 280, 331-33; Heidel 157, 171.

${ }^{61}$ In Tablet XII of the Babylonian "Series of Gilgamesh," known in antiquity as "In those days, in those far-off days" (XII 80-87), the sun god (Utu) brings the shade of Enkidu up from the Netherworld, presumably as he rises in the morning (George 175-95). There is also a reference to a Gate of Ishtar and Aya that allows passage from the underworld into the light (Livingstone 74), presumably located at the eastern horizon, compared by West 1997: 407 to Aiaie.

${ }^{62}$ The Egyptian mountains are naturalized in that there is an eastern mountain named Bakhu, and a corresponding western one named Manu, protected by lion deities (Otto, Kurth). Milde 21 notes that the mountain of the West is conceived of as an entrance to the Netherworld.

${ }^{63}$ Egyptian Book of the Dead, spells 17 (Faulkner 43-50), 109 (Faulkner 102), and 149 (Faulkner 137-45). A Ramesside text contains the claim "I am Khepri in the morning, Re in the afternoon, Atum in the evening" (Turin Papyrus 133.10, published in Rossi). 
to Dawn in the Rig Veda may also be compared to the representation of solar change in Hesiod, suggesting that the Hesiodic model was also influenced by Indo-European traditions, though they are less prominent than their Near Eastern counterparts. ${ }^{64}$

Thus, the collocation of the gate of the sun and the gate of the dead is a recurring pattern in cosmologies of the eastern Mediterranean, and there may be Indo-European analogues as well. The Egyptian and Near Eastern parallels reflect a compression of the functions of the axis mundi analogous to the Hesiodic description, spatially associating the life cycle with the solar cycle. The parallels indicate that the harmonious coexistence of uni- and bi-polar models of solar change is a common feature of mythological narratives: the twin peaks of Mashu could be conceived of as located at east and west simultaneously, or as an eastern mountain of sunrise with a matching western mountain of sunset. ${ }^{65}$ Even in the uni-polar model, there is evidence of doubling at the axial point, exemplified by the fact that there are twin peaks of Mashu at the axis mundi. The two models are thus best seen as complementary and as interacting actively with each other. ${ }^{66}$

\section{ODYSSEUS AT THE ENDS OF THE EARTH}

Austin has argued that the east : west polarity in Homer is more comprehensive, and plays a more important structuring role, than had emerged from Lloyd's earlier treatment of the theme. ${ }^{67}$ The pattern of gemination at the horizons discussed above suggests that Austin is correct in his assertion that the basic opposition between east and west extends to other conceptual spaces; hence the east is "the front, the region of rising, of beginnings, of brightness, activity, vigor, joy" while the west is "behind and below; it is murky, damp, mist-enshrouded, the region of settings and endings." ${ }^{68}$ For example, despite the close similarities between Kalypso and Kirke, a number of authors have noted that Kalypso is the more sinister of the two ${ }^{69}$ It is appropriate that

${ }^{64}$ Rig Vedai.113.2-3 and i.123.7, noted by Germain 523 and West 1966: 366 and 1997: 299-300. We may also compare Hesiod's description of Tartaros to the Norse axis mundi Yggdrasill, an ash tree whose branches stand above heaven and whose roots reach to the Netherworld (Motz).

${ }^{65}$ The relevant passages are discussed by Heimpel 140-46.

${ }^{66}$ Nagler $146 \mathrm{n} .13$ notes that the twin peaks "may thus be connected with the important abolition or, respectively, the emergence of dualities of creation at the axial point."

${ }^{67}$ Austin 90-102. Lloyd 47 denies that there exists "any developed or systematic Table of Opposites in Homer or Hesiod."

${ }^{68}$ Austin 97.

${ }^{69}$ Anderson, Frame 73-74, Crane 15-21, Louden 104-29. 
Kalypso, "the Concealer," should perform the function implied by her name in the mythical west. The chief differences between these two multiforms may therefore be seen as corresponding to their spatial associations.

If Odysseus' travels in the Apologoi can indeed be charted, not on a map of the Mediterranean, but rather at the eastern and western edges of the world, he must travel from Aiaie in the far east to the Kimmerioi and the Underworld in the far west in one day. His journey makes sense only in a coexisting uni-polar system in which the sun rises and sets in a single place..$^{70}$ That is, one where the gates of the sun, while located at opposite ends of the world, are simultaneously at its cosmological center. Odysseus sets sail from Aiaie as the sun sets, thus traveling with the sun beyond the edges of the world, returning to Aiaie as the sun rises again. ${ }^{71}$ Again, Near Eastern and Egyptian parallels are striking. Gilgamesh's journey through Mashu involves moving along "the path of the Sun god," emerging "in advance of the Sun."72 In Egyptian eschatology, boats containing the souls of the dead were thought to journey to the west by following the sun. ${ }^{73}$ Within Greek myth, this movement from one horizon to the other is paralleled by the adventures of Herakles, such as his sudden movement from Erytheia in the west to Skythia in the east, as recounted by Herodotos. ${ }^{74}$

The cruces in the Homeric descriptions of the Aithiopes, Laistrygones, and Kirke can be explained by the coexistence of two related conceptions of solar change without resorting to the geographical "guessing game" played since

${ }^{70}$ Cf. Nagy 1990: 237 and 1999: 206, who argues that Aiaie is located in the extreme west when Odysseus first arrives $(\mathrm{Od} .10 .135)$ and in the extreme east after he emerges from the underworld (Od.12.1-4). Thus, "two opposite places ... add up to the same place" (Nagy 1990: 237 and 1999: 206). My position is similar to Nagy's, but I argue that Aiaie is consistently located in the east, and that it is the conflation of uni-polar and bi-polar cosmologies that allows for Odysseus' overnight movements from the underworld to the home of the dawn goddess.

${ }^{71}$ Odysseus and his men arrive at Aiaie just prior to sunrise (Od. 12.7); see Heubeck 1992: 360-61. It is worth noting that the description of the Kimmerioi marks Odysseus' passage from Aiaie to the west, and the contrasting description of Aiaie as the "dancing floors of Dawn and the risings of Helios" appears as Odysseus returns to the eastern horizon; the descriptions therefore act as signposts of the shift in locale.

${ }^{72}$ EG IX 138 and IX 170, respectively. Cf. Burgess 192-95.

${ }^{73}$ Hornung 5-6 on the Pyramid Texts.

${ }^{74}$ Hdt. 4.8-10. Note that in Skythia Herakles encounters a woman described as a mixoparthenos, half woman, half snake. This eastern Skythian woman is balanced on the western horizon by the Hesiodic Echidna (Th.295-332), also half woman, half snake and also associated with the western labors of Herakles through her offspring Orthos and Kerberos. 
antiquity. ${ }^{75}$ I have suggested that the coexistence of uni-polar and bi-polar models of solar change results in the gemination of peoples conceived of as living at the edges of the earth. Near Eastern and Egyptian comparanda suggest that both uni-polar and bi-polar models of solar change could have coexisted for some time in Greek thought. The archaic conception of the boundary, as described by Bergren, allows for the two systems to coexist depending on one's point of view: a cosmic "outside in" conceptualization yields a single locus of solar change, while a Hellenocentric "inside out" perspective conceives of solar change occurring on the horizons. It seems likely that the unipolar model emerged in archaic Greek thought under the influence of an IndoEuropean concept of the boundary, since Greek $\pi \varepsilon i p \alpha \rho$ is cognate with parvan of Vedic Sanskrit, ${ }^{76}$ and equally through sustained contact with Near Eastern uni-polar cosmologies such as the Epic of Gilgamesh. Regardless of the origins of these models, which I have argued are structured by solar phenomena, their coexistence allows us to explain Odysseus' travels at the eschata. And the Odyssey's descriptions of fabulous places and peoples reflect a logic also expressed in the Theogony's representation of Tartaros. The explanation advanced here enriches our understanding of both poems.

\section{WORKS CITED}

Allen, A. 1993. The Fragments of Mimnermus: Text and Commentary. Stuttgart.

Anderson, W. S. 1958. "Calypso and Elysium." CJ 53: 2-11.

Austin, N. 1975. Archery at the Dark of the Moon: Poetic Problems in Homer's Odyssey. Berkeley.

Ballabriga, A. 1986. Le soleil et le tartare: L'image mythique du monde en Grèce archä̈que. Paris.

1998. Les fictions d'Homère: L'invention mythologique et cosmographique dans l'Odysée. Paris.

Beazley, J. D. 1956. Attic Black-Figure Vase-Painters. Oxford.

Bergren, A. L. T. 1975. The Etymology and Usage of ПEIPAP in Early Greek Poetry. State College, Penn.

Buffière, F. 1956. Les mythes d'Homère et la pensée grecque. Paris.

Burgess, J. 1999. "Gilgamesh and Odysseus in the Otherworld." EMC 18: 171-210.

Burkert, W. 1985 (German original 1977). Greek Religion. Trans. J. Raffan. Cambridge, Mass.

—. 1992 (German original 1984). The Orientalizing Revolution: Near Eastern Influence on Greek Culture in the Early Archaic Age. Trans. W. Burkert and M. E. Pinder. Cambridge, Mass.

${ }^{75}$ An historical summary of geographical approaches to Homeric epic can be found in Romm 1992: 172-214.

${ }^{76}$ Bergren 94. 
Carpenter, T. H., with T. Mannack and M. Mendonça. 1989 (original edition 1982). Beazley Addenda. 2nd ed. Oxford.

Clay, D. 1992. "The World of Hesiod." Ramus 21: 131-55.

Cook, E. 1992. "Ferrymen of Elysium and the Homeric Phaeacians." JIES 20: 239-67.

- 1995. The Odyssey in Athens: Myths of Cultural Origins. Ithaca.

Crane, G. 1988. Calypso: Backgrounds and Conventions of the Odyssey. Frankfurt am Main. Croon, J. H. 1952. The Herdsman of the Dead. Utrecht.

Davies, M. 1988. “Stesichorus' Geryoneis and Its Folk-tale Origins.” CQ 38: 277-90.

Dindorf, G. 1855. Scholia graeca in Homeri Odysseam. 2 vols. Oxford.

Eliade, M. 1974 (original edition 1949). Traité d'histoire des religions. Rev. ed. Paris.

Faulkner, R. O. 1985 (original edition 1972). The Ancient Egyptian Book of the Dead. Rev. ed. Austin.

Frame, D. 1978. The Myth of Return in Early Greek Epic. New Haven.

Fränkel, H. 1962 (original edition 1951). Dichtung und Philosophie des frühen Griechentums. 2nd ed. Munich.

George, A. 1999. The Epic of Gilgamesh. London.

Germain, G. 1954. Genèse de l'Odyssée. Paris.

Hainsworth, J. B. 1988. “Books V-VIII.” In A. Heubeck, S. West, J. B. Hainsworth, eds., A Commentary on Homer's Odyssey, Vol. 1. Oxford. 249-385.

Hartog, F. 1988 (French original 1980). The Mirror of Herodotus: The Representation of the Other in the Writing of History. Trans. J. Lloyd. Berkeley.

- 2001 (French original 1996). Memories of Odysseus: Frontier Tales from Ancient Greece. Trans. J. Lloyd. Edinburgh.

Hedreen, G. 1991. "The Cult of Achilles in the Euxine." Hesperia 60: 313-30.

Heidel, A. 1954 (original edition 1946). The Gilgamesh Epic and Old Testament Parallels. 2nd ed. Chicago.

Heimpel, W. 1986. "The Sun at Night and the Doors of Heaven in Babylonian Texts." JCS 38: 127-51.

Heubeck, A. 1989. “Books IX-XII.” In A. Heubeck, S. West, J. B. Hainsworth, eds., A Commentary on Homer's Odyssey, Vol. 2. Oxford. 3-143.

— 1992. "Books XXIII-XXIV." In A. Heubeck, S. West, J. B. Hainsworth, eds., A Commentary on Homer's Odyssey, Vol. 3. Oxford. 313-418.

Hoekstra, A. 1989. "Books XIII-XVI." In A. Heubeck, S. West, J. B. Hainsworth, eds., A Commentary on Homer's Odyssey, Vol. 2. Oxford. 147-287.

Hornung, E. 1999 (German original 1997). The Ancient Egyptian Books of the Afterlife.

Trans. D. Lorton. Ithaca.

Horowitz, W. 1998. Mesopotamian Cosmic Geography. Winona Lake, Indiana.

Jacoby, F., ed. 1923-. Die Fragmente der griechischen Historiker. Berlin.

Johnson, D. M. 1999. "Hesiod's Descriptions of Tartarus (Theogony 721-819)." Phoenix 53: 8-28.

Kahn, C. H. 1960. Anaximander and the Origins of Greek Cosmology. New York.

Kirk, G. S. 1990. The Iliad: A Commentary, Vol. 2. Cambridge.

Kurth, D. 1980. "Manu." In W. Helck and W. Westendorf, eds. Lexikon der Ägyptologie III.

8. Wiesbaden. 1185-86.

Livingstone, A. 1989. Court Poetry and Literary Miscellanea. Helsinki. 
Lloyd, G. E. R. 1966. Polarity and Analogy. Cambridge.

Louden, B. 1999. The Odyssey: Structure, Narration, and Meaning. Baltimore.

Merkelbach, R., and M. L. West, eds. 1990. Fragmenta selecta. With F. Solmsen, ed., Hesiodi Theogonia, Opera et dies, Scutum. 3rd ed. Oxford. 109-226.

Milde, H. 1994. "'Going out into the Day.' Ancient Egyptian Beliefs and Practices Concerning Death.” In J. M. Bremmer, Th. P. J. van den Hout, and R. Peters, eds., Hidden Futures: Death and Immortality in Ancient Egypt, Anatolia, the Classical, Biblical and Arabic-Islamic World. Amsterdam. 15-35.

Motz, L. 1991. "The Cosmic Ash and Other Trees of Germanic Myth.” Arv 47: 127-42.

Nagler, M. N. 1996. “Dread Goddess Revisited." In S. L. Schein, ed., Reading the Odyssey. Princeton. 141-61.

Nagy, G. 1990. Greek Mythology and Poetics. Ithaca.

- 1999 (original edition 1979). The Best of the Achaeans. Rev. ed. Baltimore.

Otto, E. 1973. "Bachu.” In W. Helck and E. Otto, eds., Lexikon der Ägyptologie I.4. Wiesbaden. 594.

Pellikaan-Engel, M. E. 1974. Hesiod and Parmenides: A New View on Their Cosmologies and on Parmenides' Proem. Amsterdam.

Pinney, G. F., and B. S. Ridgway. 1981. "Herakles at the Ends of the Earth.” JHS 101: 14144.

Pritchard, J. B., ed. 1969 (original edition 1950). Ancient Near Eastern Texts Relating to the Old Testament. 3rd ed. Princeton.

Radt, S., ed. 1985. Tragicorum graecorum fragmenta. Vol. 3: Aeschylus. Göttingen.

Romm, J. S. 1989. "Herodotus and Mythic Geography: The Case of the Hyperboreans." TAPA 119: 97-113.

- 1992. The Edges of the Earth in Ancient Thought. Princeton.

Rossi, F. 1981. Papyrus de Turin. Wiesbaden.

Stallbaum, G., ed. 1960 (original publication 1825-26). Eustathii ... commentarii ad Homeri Odysseam. 2 vols. in 1. Hildesheim.

van Thiel, H., ed. 1991. Homeri Odyssea. Hildesheim.

West, M. L. 1966. Theogony. Oxford.

- 1985. The Hesiodic Catalogue of Women. Oxford.

1988. “The Rise of the Greek Epic." JHS 108: 151-72.

—, ed. 1989-92. Iambi et elegi graeci ante Alexandrum cantati. 2nd ed. 2 vols. Oxford.

1997. The East Face of Helicon. Oxford.

West, S. 1988. “Books I-IV.” In A. Heubeck, S. West, J. B. Hainsworth, eds., A Commentary on Homer's Odyssey, Vol. 1. Oxford. 51-245. 